\title{
Composition and properties of atmospheric particles in the eastern Atlantic and impacts on gas phase uptake rates
}

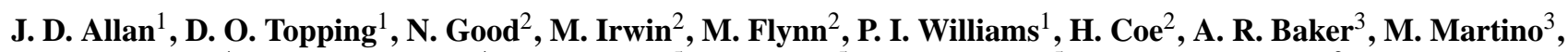 \\ N. Niedermeier ${ }^{4}$, A. Wiedensohler ${ }^{4}$, S. Lehmann ${ }^{5}$, K. Müller ${ }^{5}$, H. Herrmann ${ }^{5}$, and G. McFiggans ${ }^{2}$ \\ ${ }^{1}$ National Centre for Atmospheric Science, University of Manchester, Manchester, UK \\ ${ }^{2}$ School of Earth, Atmospheric and Environmental Sciences, University of Manchester, Manchester, UK \\ ${ }^{3}$ School of Environmental Sciences, University of East Anglia, Norwich, UK \\ ${ }^{4}$ Department of Physics, Leibniz Institute for Tropospheric Research, Leipzig, Germany \\ ${ }^{5}$ Department of Chemistry, Leibniz Institute for Tropospheric Research, Leipzig, Germany
}

Received: 19 August 2009 - Published in Atmos. Chem. Phys. Discuss.: 3 September 2009

Revised: 18 November 2009 - Accepted: 1 December 2009 - Published: 11 December 2009

\begin{abstract}
Marine aerosol composition continues to represent a large source of uncertainty in the study of climate and atmospheric chemistry. In addition to their physical size and chemical composition, hygroscopicity plays a significant role, increasing the particles' surface areas and scattering potential. Simultaneous aerosol measurements were performed on board the RRS Discovery and at the Cape Verde atmospheric observatory during the Aerosol Composition and Modelling in the Marine Environment (ACMME) and Reactive Halogens in the Marine Boundary Layer (RHAMBLE) experiments. These included online measurements of number and dry size and bulk collection for offline analysis of aqueous ions. In addition, the measurements on board the Discovery included online measurements of composition using an Aerodyne Aerosol Mass Spectrometer, optical absorption using a Multi Angle Absorption Photometer, ambient humidity size distribution measurements using a humidified differential mobility particle sizer (DMPS) and optical particle counter (OPC) and hygroscopicity measurements with a hygroscopicity tandem differential mobility analyser (HTDMA).

Good agreement between platforms in terms of the sea salt (ss) and non sea salt (nss) modes was found during the period when the Discovery was in close proximity to Cape Verde and showed a composition consistent with remote marine air. As the Discovery approached the African coast, the aerosol showed signs of continental influence such as an increase
\end{abstract}

in particle number, optical absorption, enhancement of the nss mode and dust particles. The Cape Verde site was free of this influence during this period. Chloride and bromide showed concentrations with significant deviations from seawater relative to sodium, indicating that atmospheric halogen processing (and/or acid displacement for chloride) had taken place. The time dependent ambient size distribution was synthesised using humidified DMPS and OPC data, corrected to ambient humidity using HTDMA data. Heterogeneous uptake rates of hypoiodous acid (HOI) were also predicted and the nss accumulation mode was found to be the most significant part of the size distribution, which could act as an inert sink for this species. The predicted uptake rates were enhanced by around a factor of 2 during the African influence period due to the addition of both coarse and fine particles.

The hygroscopicity of the nss fraction was modelled using the Aerosol Diameter Dependent Equilibrium Model (ADDEM) using the measured composition and results compared with the HTDMA data. This was the first time such a reconciliation study with this model has been performed with marine data and good agreement was reached within the resolution of the instruments. The effect of hygroscopic growth on HOI uptake was also modelled and ambient uptake rates were found to be approximately doubled compared to equivalent dry particles. 


\section{Introduction}

The composition of marine boundary layer (MBL) aerosols continues to be a highly relevant field of study to atmospheric science. While oceans represent the majority of the earth's surface, this environment remains poorly characterised relative to continental environments. In addition to particles composed of sea salt, unperturbed MBL aerosols are known to contain significant contributions from the oxidation products of dimethyl sulphide (DMS), chiefly sulphate and methyl sulphonic acid (MSA) (Ayers et al., 1991). In addition, MBL aerosol particles have on occasion been found to contain significant amounts of organic matter (Novakov and Penner, 1993). In addition to anthropogenic sources, this fraction has partly been linked to biological activity in the ocean (Novakov et al., 1997; O'Dowd et al., 2004; Kawamura and Gagosian, 1987), although the governing mechanisms and importance of this fraction are currently the subject of debate (Allan et al., 2008; Facchini et al., 2008; Mochida et al., 2007).

As well as radiative effects that perturb meteorology and climate (Forster et al., 2007), particles are known to play a big part in atmospheric chemistry by facilitating many heterogeneous and multiphase processes, which can greatly alter the atmospheric processing of emissions (Ravishankara, 1997). One category of such processes is the cycling of halogens, an important process within the marine boundary layer (Sander et al., 2003). This has the potential to significantly alter the oxidative budget of the remote atmosphere, influencing sulphate formation, ozone concentrations and the lifetime of pollutants (Read et al., 2008; von Glasow et al., 2002).

Fundamental to our understanding of these processes is how the particles interact with water vapour in the atmosphere. Particles with a high water affinity will take up moisture in high humidity conditions, increasing their size and in turn increasing their ability to scatter light and their single scattering albedo (Quinn et al., 2005), with the associated effects on the radiative budget. Additionally, an increase in the physical size of the particles will increase the surface area presented to the gas phase, which will increase the rate at which gas phase reactants are absorbed into it (Schwartz, 1986). If there are any multiphase processes that are uptake-limited, this will increase the rate at which these processes occur accordingly. Conceptually, composition could also dictate the occurrence of phase changes (deliquescence/efflorescence) that may accompany changes in relative humidity $(\mathrm{RH})$. This will affect interactions with the gas phase by altering accommodation coefficients and the bulk/surface transport of reactants within the particle.

The diameter growth factor (GF) of an aerosol particle as a function of RH is defined as the humidified/wet size $\left(D_{\mathrm{RH}}\right)$ divided by its dry size $(D 0)$. Calculating this change in size as a function of relative humidity is carried out using the Kohler equation (Köhler, 1936). This describes the effect of two competing factors on the equilibrium water content of a particle; the Raoult (solute) term, which accounts for bulk intermolecular interactions on the water activity, or "effective" concentration of water and the Kelvin (curvature) term, which accounts for the increase in vapour pressure of water above a curved surface, the dependency on composition manifest in the surface tension of the mixed solution. For subsaturated conditions, the dependency of the growth factor on particle composition is mainly captured in the Raoult term, the impact of surface tension becoming important only at higher relative humidities $(\mathrm{RH}>95 \%)$. A major determinant of the growth factors of submicron atmospheric particles is the proportion of weakly soluble organic species and elemental carbon relative to the more soluble inorganic fraction, which is typically sulphates and nitrates (Gysel et al., 2007). However, another potentially major influence is the $\mathrm{pH}$ of the inorganic fraction; more acidic solutions will have a much greater propensity to take on water (Clegg et al., 1998). This will be a major factor in the marine atmosphere, as much of the non sea salt (nss) fraction is made up of sulphuric acid and MSA produced from the oxidation of dimethyl sulphide (Quinn et al., 1993), although $\mathrm{SO}_{2}$ from shipping and long range transport will also contribute to the sulphuric acid budget. In the terrestrial boundary layer, gas phase ammonia tends to be more abundant, so the sulphurous aerosols are most commonly in the form of ammonium sulphate. While there are sources of ammonia in the marine environment (Jickells et al., 2003), it is not as abundant in the remote MBL and therefore particulate ammonium concentrations are typically less than what would be sufficient to neutralise the sulphate present (Allan et al., 2004a; Coe et al., 2006; Allan et al., 2008).

In order to quantify the role aerosols have in processes such as atmospheric chemistry and the earth's radiation budget, it is desirable to have the ability to predict hygroscopicity using a "bottom up" approach from explicit composition data, either obtained from in situ measurements or the outputs of aerosol composition models. The advantage of this explicit linkage is the ability to capture process level phenomena. Once the detailed models are validated, they can be used as they are or employed to generate more informed parameterisations for use in higher-level models. This will reduce the need for arbitrary parameterisations and tunings and in turn, help to improve overall model skill.

While well-established models exist that can provide such a treatment for the inorganic fraction (e.g. Clegg et al., 1998), modelling the mixed inorganic-organic system is inherently more challenging. One model that attempts to perform this explicitly is the Aerosol Diameter Dependent Equilibrium Model (ADDEM) (Topping et al., 2005a, b). This is a thermodynamic equilibrium model that treats the complex solute-water interactions of both the inorganic and organic fractions explicitly, coupling water contents from both fractions using an additive approach. Given its cost, it is not suitable for use within large-scale models, but instead can be used as a benchmark model, against which lower-cost 
parameterisations may be validated. However, this model in itself must be validated against real-world data and while reconciliation exercises have been performed using terrestrial data (McFiggans et al., 2005; Gysel et al., 2007), it has yet to be tested against ambient observations in the marine environment.

Here we present measurements taken in the eastern Atlantic MBL in 2007. Reconciliation is assessed and the sensitivity to the measurement and inversion uncertainties is discussed. The effects the aerosol composition, microphysical properties, hygroscopicity and the associated uncertainties may have on gas phase uptake rates is also considered.

\section{Experimental}

The data presented here are principally associated with two projects within the UK Surface-Ocean/Lower Atmosphere Study (SOLAS) thematic programme: Aerosol Composition and Modelling in the Marine Environment (ACMME) and Reactive Halogens in the Marine Boundary Layer (RHAMBLE). ACCME is a ship-based project designed to study marine aerosol composition, hygroscopicity, cloud condensation nucleus $(\mathrm{CCN})$ potential and their implications for heterogeneous and multiphase chemistry and cloud microphysics. The $\mathrm{CCN}$ aspects of this work are presented in Good et al. (2009) and the cloud interaction and more comprehensive halogen cycling aspects will be presented in future publications. RHAMBLE is a multi-platform study designed to study the role of reactive halogen processes in marine environments and is described in more detail in other papers in this issue. The results presented here are from coastal measurements performed at Cape Verde and the simultaneous measurements performed aboard the RRS Discovery, part of the NERC marine research fleet.

\subsection{Measurements on the RRS Discovery}

The RHAMBLE cruise (D319) took place aboard the RRS Discovery during May and June 2007. After departing from Lisbon, the ship travelled down to Cape Verde via the Canary Islands. From there, the ship travelled to the Mauritanian upwelling region, performing a number of incursions into the most biologically active areas as identified using satellite chlorophyll data products. Afterwards, the ship returned to the UK via the Canaries. More details of the location of the remote marine measurements in RHAMBLE are given in Lee et al. (2009), within which the ship track is shown in Fig. 3.

A number of online aerosol instruments were deployed during D319 in the Manchester Centre for Atmospheric Science (CAS) shipping container, which was mounted on the forecastle deck. Air was drawn in through a $10 \mathrm{~m}$ vertical inlet stack, through a $2.5 \mu \mathrm{m}$ cutoff cyclone and then distributed through the container through a horizontal manifold, using isokinetic sampling ports. Online composition was measured using an Aerodyne Research Inc. (Billerica, MA, USA) High Resolution Aerosol Mass Spectrometer (HR-AMS) (Canagaratna et al., 2007; DeCarlo et al., 2006). The standard techniques for sampling, calibration and data analysis were used, as recorded elsewhere in the literature (Allan et al., 2004b; Allan et al., 2003; Jayne et al., 2000; Jimenez et al., 2003). $350 \mathrm{~nm}$ ammonium nitrate particles were used for the ionisation efficiency calibration. The collection efficiency (CE) was assumed to be 0.5 and was validated by comparisons with the submircron nss sulphate derived from the collocated impactors.

In addition to the AMS, a Thermo Fisher Scientific Inc. (Waltham, MA, USA) model 5012 Multi Angle Absorption Photometer (MAAP) (Petzold et al., 2005) was used to measure equivalent black carbon. This is a useful marker for refractory soot particles to which the AMS is insensitive. A Hygroscopicity Tandem Differential Mobility Analyser (HTDMA) was deployed to measure the particle growth factors at $90 \% \mathrm{RH}\left(\mathrm{GF}_{D 0,90}\right)$ and periodically measure growth factors as a function of RH to generate humidograms. The HTDMA used has been previously described by Cubison et al. (2005) and was modified for operation at sea by replacing the water cooling system with an insulated temperature controlled box enclosing the second humidified DMA. A PID controlled thermoelectric cooler (Supercool models AA-060-12-22 and PR59, Gothenburg, Sweden) maintained the second DMA a constant temperature of $18 \pm 0.1^{\circ} \mathrm{C}$, approximately $2{ }^{\circ} \mathrm{C}$ lower than the mobile laboratory. Quality assurance and inversion of the HTDMA data was performed using the procedures and the multi-triangle inversion method described by Gysel et al. (2009).

Aerosol number size distributions were measured using a combination of differential mobility particle sizers (DMPS) (Williams et al., 2000) and an Optical Particle Counter (OPC, Grimm Aerosol Technik GmbH \& Co. KG model 1.108, Ainring, Germany), in a manner similar to that performed previously by Williams et al. (2007). In order to reduce losses of coarse particles and to size the particles as close to ambient temperature and humidity as possible, the OPC was placed inside a box located next to the inlet of the container sampling stack. For the purposes of using the data for chemical modelling studies, it was necessary to obtain a submicron size distribution relevant to ambient relative humidities. To this end, two DMPS systems were operated in parallel, one with dry sheath air $(<20 \% \mathrm{RH})$ and one with the sheath air matched to the ambient relative humidity (approximately $80 \%$ ). These are known hereafter as the "dry" and "wet" DMPS systems respectively

A combination of samplers was used for the offline analysis of particulates. During D319, a 4-stage Harvard compact cascade impactor (CCI) (Demokritou et al., 2004) with cutpoints of $0.16,1.0,5.3$ and $9.9 \mu \mathrm{m}$ was deployed and loaded with polyurethane foam (PUF) substrates. The sampling point was collocated with the CAS container aerosol 

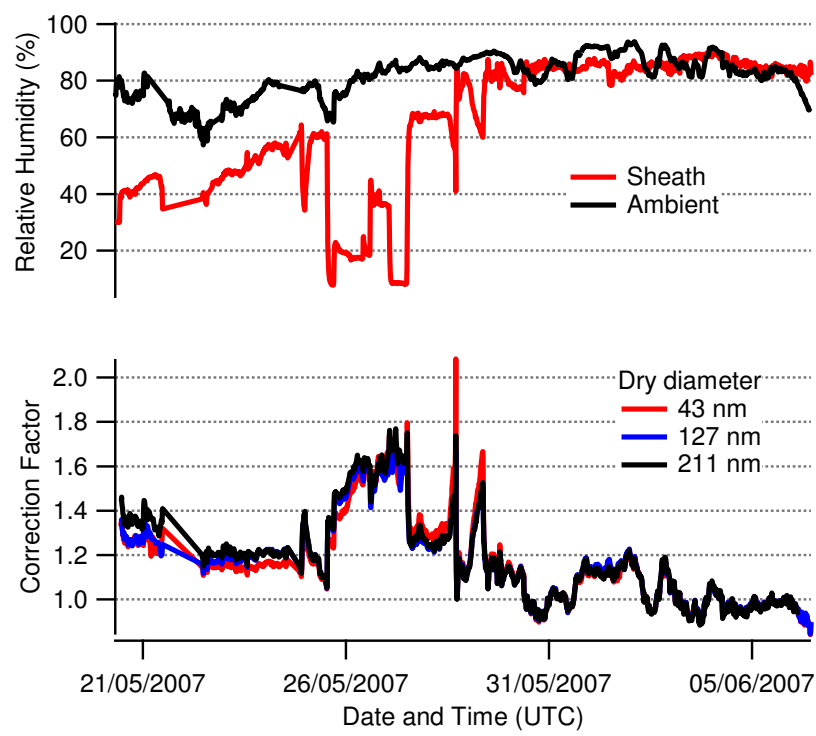

Fig. 1. Correction factors for the wet DMPS diameters derived from the parameterised humidograms and mean $\mathrm{GF}_{D 0,90}$ values from the HTDMA.

inlet, using a dedicated sampling stack with the impactor cassette located directly below. Samples were taken daily and analysed offline at the University of Manchester for inorganic aqueous ions using ion chromatography, UV-visible spectrophotometry and inductively coupled plasma atomic emission spectrometry.

In addition, an Anderson high-volume sampler equipped with a Sierra-type cascade impactor was deployed on the "monkey island" above the wheelhouse. The advantage of the Anderson over the CCI was that it used a much higher flow rate, which improved accuracy and detection limits, although the CCI did have a greater number of size stages and reduced possibility of particle bounce. The sampling point was slightly higher and further back along the ship compared to the container on the forecastle. A second OPC was located next to these to compare with the measurements being made at the CAS container and the number concentrations were found to be almost identical between the two locations.

The cascade impactor was fitted with two upper stages (3 and 4) and a backup filter and loaded with Whatman 41 cellulose substrates (Maidstone, Kent, UK). The two upper stages were combined to give the supermicron fraction, while the backup filter contained the submicron fraction. Samples were taken daily and were analysed at the University of East Anglia for aqueous ions, including bromide and speciated iodine, as described previously (Baker, 2004, 2005; Baker et al., 2007).

\subsubsection{Synthesising the ambient size distribution}

For the purpose of assessing the effect of aerosols on heterogeneous and multiphase chemistry, a final "ambient" size resolved number matrix was generated, taking into account the effect of ambient humidity on the size distribution. The data from the wet DMPS and OPC were mapped into 64 geometrically spaced size bins between $10 \mathrm{~nm}$ and $10 \mu \mathrm{m}$ diameter as a $d N / d \log \left(D_{p}\right)$ distribution. It is expected that there will be a disconnect between the two sizing instruments due to ambiguities in the optical sizing of the particles. This was overcome by taking an average of the two instruments within the overlapping bins of the size distribution (around $352-437 \mathrm{~nm}$ ). While not perfect, this serves as the best possible estimate of the ensemble size distribution without making assumptions regarding particle refractive indices and instrument response to aspherical particles.

While the sheath humidity of the wet DMPS was kept as close to ambient RH as possible, there was often a difference of a few percent between the instrument and ambient RH (see Fig. 1). In order to assess and mitigate any effect this caused, the HTDMA data were employed. Least-squares fits were made to the recorded humidograms using the following 3factor parameterisation (Eq. 17 in Kreidenweis et al., 2005):

$\mathrm{GF}_{D 0, a_{\mathrm{w}}}=\left(1+\left(a+b a_{\mathrm{w}}+c a_{\mathrm{w}}^{2}\right) \frac{a_{\mathrm{w}}}{1-a_{\mathrm{w}}}\right)^{\frac{1}{3}}$

Where $a_{\mathrm{w}}$ is the water activity and $a, b$ and $c$ are arbitrary fitting parameters. For the purpose of this parameterisation, the water activity was assumed to be the fractional RH. The parameterisation formula was rearranged so that the $a$ parameter can be replaced with $\mathrm{GF}_{D 0,90}$, the growth factor at $90 \%$ $\mathrm{RH}$. It can also be formulated to take $\mathrm{RH}$ as a percentage:

$\mathrm{GF}_{D 0, \mathrm{RH}}$

$=\left(1+\left(\frac{\mathrm{GF}_{D 0,90}^{3}-1}{9}+b^{\prime}(\mathrm{RH}-90)+c^{\prime}\left(\mathrm{RH}^{2}-8100\right)\right) \frac{\mathrm{RH}}{100-\mathrm{RH}}\right)^{\frac{1}{3}}$

The arbitrary fitting parameters $b$ and $c$ are replaced with $b^{\prime}$ and $c^{\prime}$, which are, in effect, the previous parameters multiplied by $10^{-2}$ and $10^{-4}$ respectively. These parameters were derived for three diameters $(43,127$ and $211 \mathrm{~nm})$ for 5 humidograms performed during the study (those taken overnight on 22/05, 24/05, 29/05, 31/05 and 4 June 2007). Note that this approach only works if there are no phase changes occurring within the range of humidity used. Given that no such transitions were noted in the ambient humidograms, this seems to be a safe assumption. While $b^{\prime}$ and $c^{\prime}$ were both allowed to vary freely and returned values in the range of $-2.367 \times 10^{-4}$ to 0.1554 and $-4.019 \times 10^{-5}$ to $-9.309 \times 10^{-4}$ respectively, they were found to be not independent, with all of the derived values for all dry sizes conforming to the relationship $b^{\prime}=-9.791 \times 10^{-3}-172.3 c^{\prime}$ with an $r^{2}$ of 0.996 .

By applying the measured mean $\mathrm{GF}_{D 0,90}$ values with the derived values of $b^{\prime}$ and $c^{\prime}$ linearly interpolated between measured humidograms, simulated growth curves could be generated as a function of time. By performing lookups of the 
ambient and wet DMPS sheath humidity, a diameter correction factor could be derived for all points within the dataset (see Fig. 1). This factor was found to be largely invariant with respect to $D 0$ so the average of the three factors was used for all wet DMPS diameters during the mapping onto the prescribed grid.

In practice, this turned out to be a small correction when the humidifier was working correctly, resulting in modifications to the diameter of less than $20 \%$ for the majority of the campaign. However, during a period between 2529 May 2007, the humidifier was not operational, so corrections of up to $60 \%$ were needed. Note that this correction only applies to the ambient size distribution reported, not the hygroscopicity measurements which are the subject of the ADDEM model reconciliation work in this paper.

\subsection{Measurements at Cape Verde atmospheric observatory}

Simultaneous to the cruise, an extended period of measurements was being performed at the observatory at Cape Verde. More information is contained within Lee et al. (2009). Bulk samples for chemical analysis were taken at the Cape Verde observatory with a Digitel Elektronik AG (Hegnau, Switzerland) model DHA-80 high-volume sampler on Munktell MK $360150 \mathrm{~mm}$ quartz fibre filters (Bärenstein, Germany). The instrument was exposed on top of a $30 \mathrm{~m}$ tower to avoid strong sea spray influences from the nearby coastline. From 14 May until 14 June 2007 the sampler was mainly operated in daily mode, but due to a very low dust concentration from 25 May until 8 June 2007, the frequency was switched to $48 \mathrm{~h}$. The samples were analysed offline for mass concentrations and inorganic ion concentrations at the Leibniz-Institut für Troposphärenforschung e.V. in Leipzig. These measurements are described in more detail by Müller et al. (2009).

The physical characterisation equipment was housed in an air conditioned container at ground level. The inlet was mounted about $4 \mathrm{~m}$ above ground with a $\mathrm{PM}_{10}$ inlet on the top and a $2 \mathrm{~m}$ stainless steel tube leading to the inside of the container. Aerosol number size distributions were measured using a Scanning Mobility Particle Sizer (SMPS) (Birmili et al., 1999) with a volume equivalent diameter range of 0.01 to $0.8 \mu \mathrm{m}$ in parallel with a TSI Inc. (Shoreview, MN, USA) model 3321 Aerodynamic Particle Sizer (APS) providing an aerodynamic diameter range from 0.5 to $10 \mu \mathrm{m}$. To avoid particle losses due to sedimentation, the APS was installed directly below the inlet. The combination of mobility size distributions from the SMPS and aerodynamic size distributions from the APS was conducted by assuming a density of $2.2 \mathrm{~g} \mathrm{~cm}^{-3}$ and a shape factor of 1.1 and converting the aerodynamic diameters to volume equivalent diameters (DeCarlo et al., 2004). At least 9 diameters covered the range of the overlapping distributions.

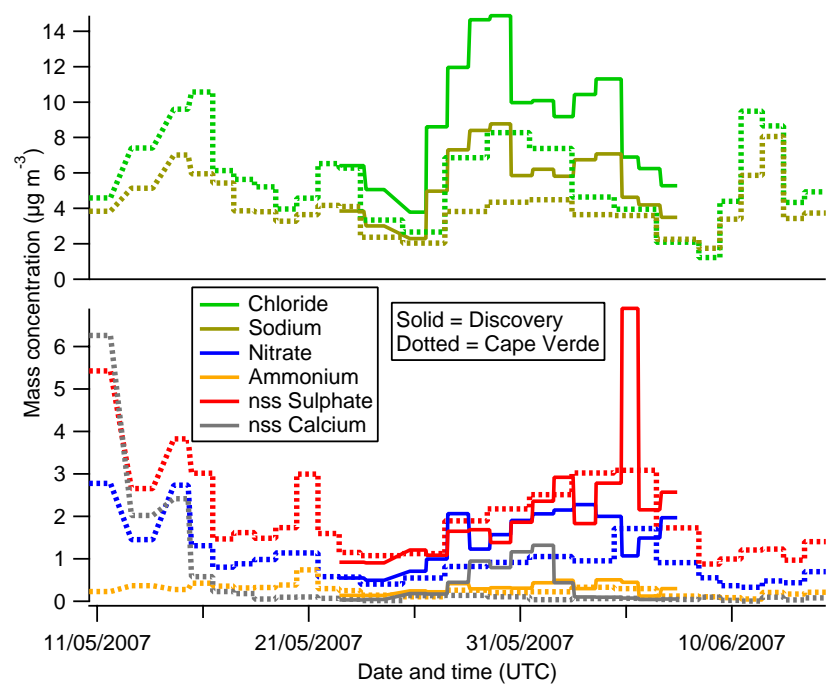

Fig. 2. Total inorganic mass loadings taken from the offline analysis of filters and high-volume impactor samples. Arrows denote approximate locations of the RRS Discovery during the study.

\section{Results}

\subsection{Overview}

The inorganic component mass loadings of the Cape Verde filter samples are shown in Fig. 2. As would be expected of a marine environment, the majority of the mass collected originated from sea salt. However, there were appreciable amounts of nss sulphate, ammonium and nitrate present as well. The nss fractions were calculated after the subtraction of the sea salt fraction predicted based on the sodium concentrations and the ionic composition of seawater (Millero, 1974). By way of comparison, the total concentrations derived from the high-volume sampler on the Discovery are also shown in Fig. 2. MSA loadings (not shown) were small, averaging only $0.05 \mu \mathrm{g} \mathrm{m}^{-3}$ on the Discovery. This is in line with the smaller fractional MSA yields from DMS previously reported for equatorial latitudes (Bates et al., 1992).

The two measurements are in good general agreement for the sea salt species when the Discovery was close to Cape Verde (around 25-26 May 2007). As the Discovery travelled east and approached Africa, the concentrations of sodium and chloride increased. This is coincident with the wind speed increasing from around 5 to $12 \mathrm{~m} \mathrm{~s}^{-1}$, although it may also be that production from upwind coastal surf zones may have been contributing (O'Dowd and De Leeuw, 2007, and references therein). Nitrate concentrations also increased, which is likely to be due to nitric acid originating from terrestrial $\mathrm{NO}_{\mathrm{x}}$ sources depositing onto sea salt particles (Baker et al., 2007; Topping et al., 2004).

On 27 May 2007, the Discovery measurements began to report appreciable amounts of soluble nss calcium, which is consistent with wind-driven Saharan dust particles 


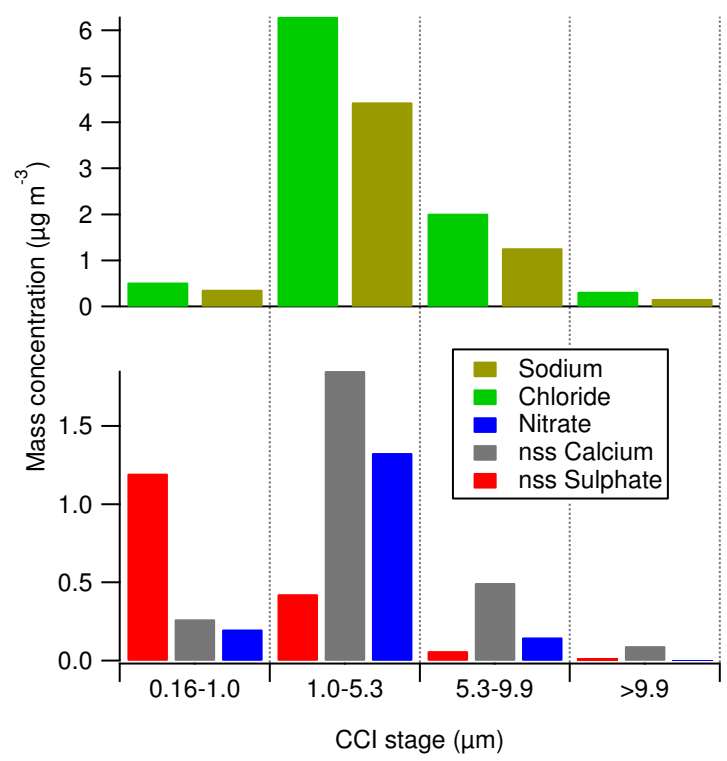

Fig. 3. Size-distributed inorganic aerosol composition as collected by the Discovery CCI during part of the African-influenced period (30-31 May 2009).

previously seen in this environment (Formenti et al., 2003; Baker et al., 2003; Baker et al., 2007). Most of the calcium is probably suspended in the form of relatively insoluble calcite $\left(\mathrm{CaCO}_{3}\right)$ (Claquin et al., 1999), although this may be transformed into a more soluble form (such as calcium nitrate) through atmospheric processing or during sample extraction. Conversely, nss calcium was not present at Cape Verde during that time, implying that unlike the Discovery, the site was largely free of African influences during the cruise period (although a similar elevation was seen earlier in the campaign during the period 10-16 May 2007). Interestingly, the two datasets were largely in agreement for sulphate, implying that proximity to Africa was not increasing the sulphate concentrations over the marine background.

When the CCI samples taken during the Africaninfluenced period are viewed as a function of size (Fig. 3), it can clearly be seen that the nss sulphate is favoured in the submicron stage whereas the other components are largely contained within the $1-5.3 \mu \mathrm{m}$ range. Based on the shape of the distribution, the nitrate appears to be associated with the coarse particles, which is consistent with sea salt or dust particles taking up nitric acid from the gas phase.

The general phenomenology was also reflected in the particle number concentrations reported from the two platforms shown in Fig. 4. For the majority of the period 16 May17 June 2007, the total particle number concentrations (measured by integrating the size-resolved data from the combined SMPS and APS measurements) varied slowly and rarely increased above $1000 \mathrm{~cm}^{-3}$. The ensemble Discovery measurement (taken from the wet DMPS and the OPC)

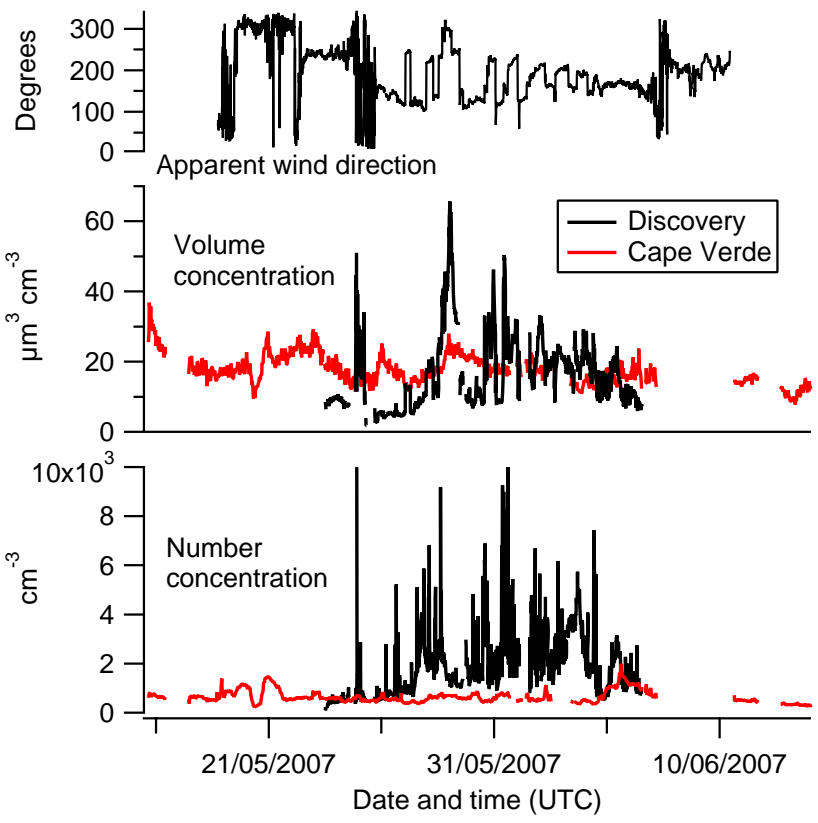

Fig. 4. Derived number and volume concentrations from Cape Verde and the Discovery. The apparent wind direction is taken from the raw data of the Discovery's weather station (giving wind bearing relative to stern), uncorrected for the heading and speed of the ship.

was in agreement when the ship was close to Cape Verde, but as it approached the African coast, concentrations began to increase. A large increase was noted on 17 May 2007 and after this event, concentrations were as much as $3000 \mathrm{~cm}^{-3}$ greater than the simultaneous Cape Verde measurements.

Figure 4 also shows the volume concentrations derived from the sizing data. The agreement is generally poor when comparing the two platforms, but this is not unexpected given the differences in the sampling locations and proximity of the Cape Verde physical measurements to the local surf zone. When the Discovery volume concentrations after 26 May 2007 are inspected (which is mainly a function of the upper size channels of the OPC data), a number of step changes can be noted which coincide with the ship changing direction. This is because the CAS container inlet was situated on the starboard side of the ship's fore and whenever the apparent wind was originating from the port bow (this occurred principally when the ship was heading east), the air had to pass the ship's forward A-frame before being sampled. It appears that this was removing a fraction of the larger coarse particles through impaction. This issue will have affected the CCI and ensemble sizing measurements but not the high-volume samples, which were taken higher up and further aftward on the ship. During the period 26-28 May 2007, the high-volume analysis reported approximately $29 \%$ greater supermicron sodium concentrations than the CCI. 


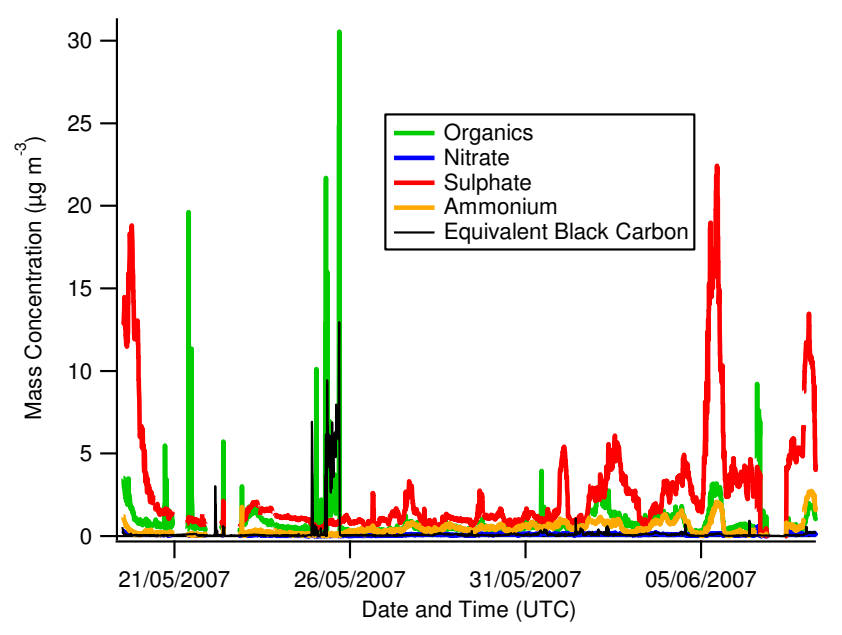

Fig. 5. Mass concentrations reported by the AMS and MAAP on board the Discovery.

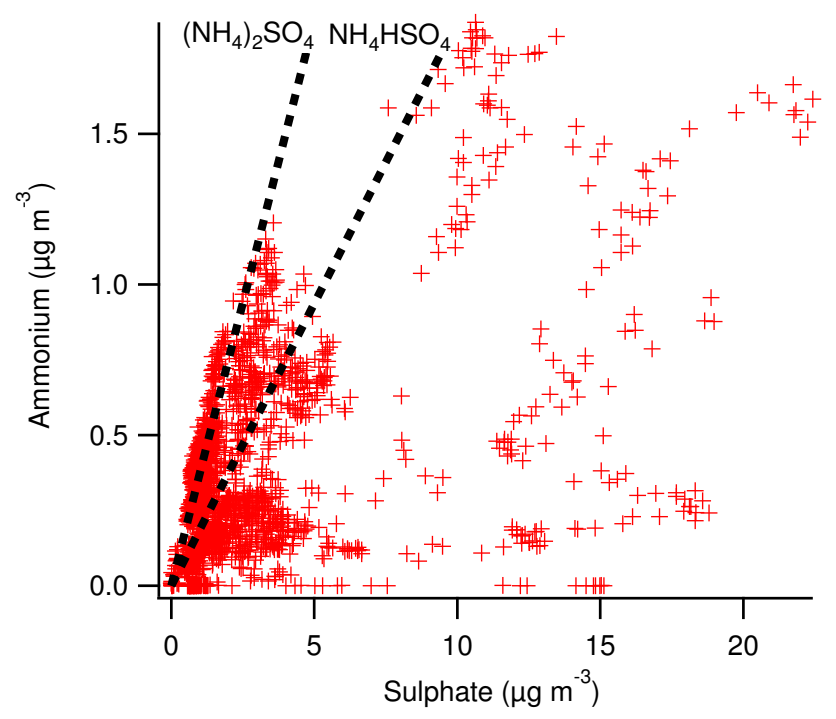

Fig. 6. Ammonium and sulphate derived from the AMS for the cruise. The high sulphate events all occurred during the European influenced periods at the beginning and end of the cruise. The dotted lines indicate the mass ratios that would correspond to ammonium sulphate and ammonium bisulphate.

The AMS and MAAP measurements (Fig. 5) were less distinct in this behaviour. A general increase in sulphate, organics and ammonium was recorded as the ship approached Africa but not as dramatically as the number or calcium measurements. The ammonium to sulphate molar ratio (Fig. 6) generally varied between 1 and 2, with full neutralisation rarely being reached. The reported equivalent black carbon (EBC) concentrations (using the factory default mass specific absorption of $6.67 \mathrm{~m}^{2} \mathrm{~g}^{-1}$ ) were generally very small, except for when the ship was berthed at Lisbon (until 19 May 2007)

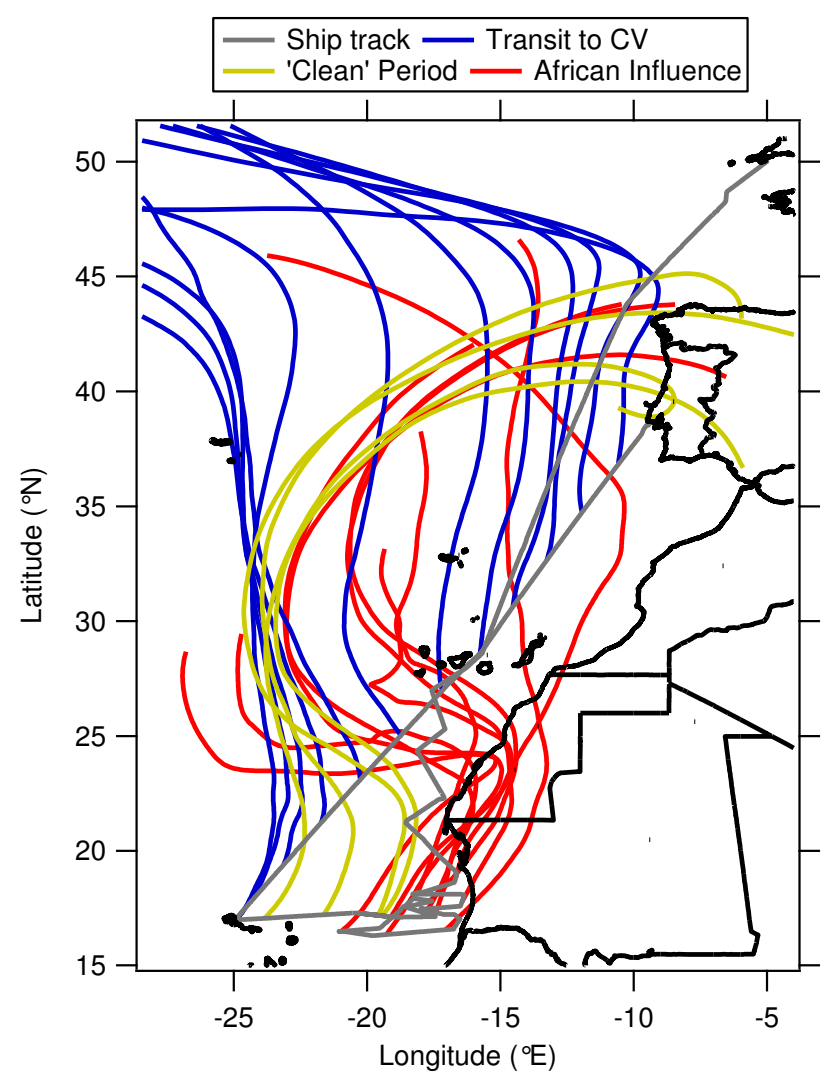

Fig. 7. Five-day ECMWF back trajectories during the initial transit and the case study periods during the RHAMBLE cruise (D319) of the RRS Discovery.

or Cape Verde (on 25 May 2007), where emissions from land vehicles, the Discovery and other ships were probably contributing. At other times, no spikes that would be associated with sampling the ship's own exhaust are seen. However, the reported values of EBC should be treated with caution, as the values could be influenced by other forms of optically absorbing particulate such as organic matter or dust (Lack et al., 2008; Haywood et al., 2003). While these do not absorb light as strongly as black carbon, their quantities relative to the reported EBC during these measurements are enough to render it questionable as a measure of elemental carbon. The AMS-reported nitrate too is quite small, which is a common observation in marine environments (Allan et al., 2008; Coe et al., 2006). In these circumstances, it is questionable to ascribe the reported nitrate to ammonium nitrate, as it is known other sources such as sodium nitrate and organic nitrogen can contribute to the signal (Allan et al., 2006; Allan et al., 2004a).

\subsection{Air mass classification}

These qualitative observations of the composition can be broadly explained through the analysis of ECMWF back 


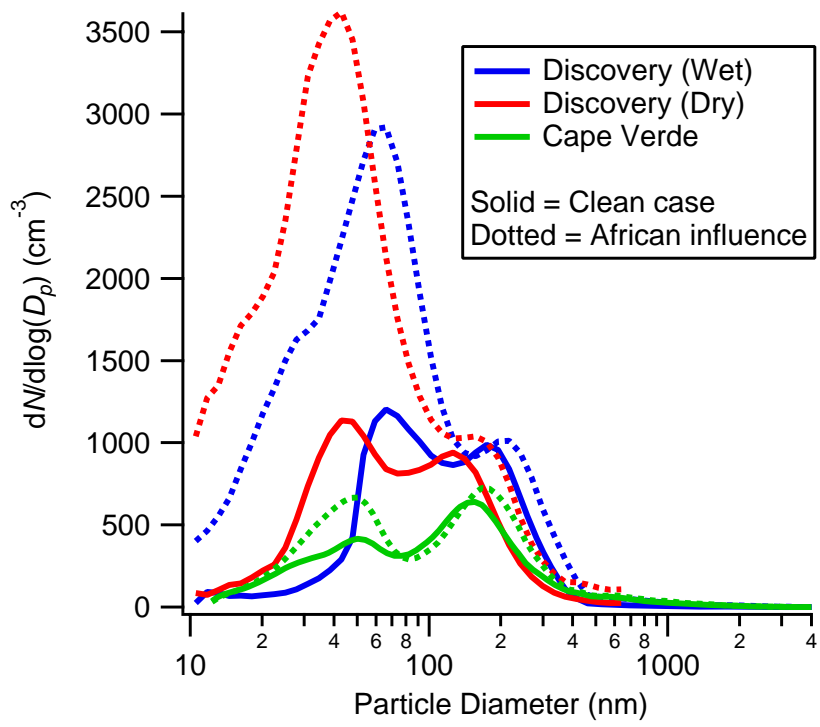

Fig. 8. Averaged size distributions for the two case study periods, taken from the composite size distributions of the two platforms (DMPS and OPC in the case of the Discovery, SMPS and APS in Cape Verde). Note the relative similarity between cases in the Cape Verde data, consistent with the notion that the extent of the African influence did not reach Cape Verde.

trajectories (arriving at a pressure altitude of $950 \mathrm{hPa}$ ), as shown in Fig. 7. During the initial transit to Cape Verde, the majority of the air masses originated from the northern Atlantic. After leaving Cape Verde, the back trajectories came from the north, going to the east only once they were north of Africa. This changed around midday on 27 May 2007, when back trajectories started originating from over Africa. This was coincident with the significant increase in number concentrations and nss calcium that was seen. These general conditions persisted until the ship travelled north, when the nss calcium concentrations decreased. After this, while the back trajectories did not travel over mainland Africa, they indicate that the ship was influenced by emissions from the Canary Islands and the Iberian Peninsula.

Based on this analysis, general case study periods can be identified for the purpose of modelling studies. While the conditions prior to the ship reaching Cape Verde seem to be the most suitable for the analysis of background MBL aerosols, poor data coverage from the hygroscopicity instruments meant that this period is unsuitable for analysis. The period after the West African influence is also deemed unsuitable because of the high variability in the composition and airmass histories. After excluding these periods, two case study periods can be identified; a "clean" period after leaving Cape Verde (18:00 25 May-10:00 27 May 2007 UTC) and an "African influence" period when the ship was in the Mauritanian upwelling region (13:00 28 May-14:00 1 June 2007 UTC). A summary of the observations averaged to these periods is shown in Table 1, with the initial transit period also given for the sake of comparison.

The averaged size distributions are shown in Fig. 8 from the ensemble distributions of both platforms. The two cases are very comparable to the remote and polluted MBL cases identified by Raes et al. (2000). The clean case is certainly very similar, with a classic bimodal spectrum seen in the DMPS number distribution, featuring distinct Aitken and accumulation modes (Hoppel et al., 1986). The averaged composite distribution from Cape Verde for the clean case shows qualitatively the same features, albeit with different contributions from the modes, which given the geographical separation, isn't unexpected. The generally elevated coarse number concentrations reported from the Cape Verde data will be due to the influence of the local surf zone, although the A-frame influence may be partially contributing to the discrepancy. The agreement in the total number concentrations between the wet and dry instruments is very good during the clean period but there is a discrepancy in the Aitken mode during the African influence period. This probably results from a mismatch in the temporal coverage of the two instruments, as the number concentrations in this size range were highly variable.

The African-influenced period shows a great enhancement in the Aitken-mode particles and an overall increase in the number of particles of all sizes in the Discovery data. By way of comparison, the Cape Verde distribution showed little change during this period. The total ambient particulate volume increased by a factor of approximately 4 from 5.9 to $23.5 \mu \mathrm{m}^{3} \mathrm{~cm}^{-3}$, although as stated earlier, these values must be treated with caution as they are strongly dependent on the sizing accuracy of the OPC. There was a corresponding increase in supermicron sea salt concentrations at the same time as reported by the CCI (this sampler is used for comparison as any artefacts caused by the A-frame influence should affect both measurements equally), however this was only a factor of 2.3 increase from 9.5 to $22.0 \mu \mathrm{g} \mathrm{m}^{-3}$. The increase in dust concentrations will have contributed significantly to the extra volume, but as the impactor analyses capture an indeterminate fraction of the calcium content (dependent on the exact composition and extraction procedure), this can only be taken as a qualitative indicator. There was no systematic increase in RH during the African influence, so the fractional water content of the particles is unlikely to be responsible for the measured change in volume.

\section{Modelling hygroscopicity}

The HTDMA data showed up to three growth modes, as shown in Fig. 9; a low hygroscopicity mode at approximately $\mathrm{GF}_{D 0, \mathrm{RH}}=1.1$, intermediate hygroscopicity mode at $1.6-1.7$ and a high hygroscopicity mode at 2 . The dominant intermediate hygroscopicity mode will correspond to the nss accumulation mode, which will be composed principally of sulphate, ammonium and organics as measured by the AMS. 
Table 1. Summary of key aerosol composition measurements during the case study periods, expressed as means and standard deviations. All units $\mu \mathrm{g} \mathrm{m}^{-3}$ unless stated.

\begin{tabular}{lllll}
\hline Instrument & Measurement & Transit to CV & "Clean" period & African Influence \\
& & $22 / 05$ 21:00-24/05 21:00 & 25/05 18:00-27/05 10:00 & $28 / 05$ 13:00-01/06 14:00 \\
\hline & Chloride & $5.7 \pm 0.95$ & $6.2 \pm 3.4$ & $12 \pm 3.4$ \\
& Sodium & $3.4 \pm 0.59$ & $3.6 \pm 1.9$ & $7.3 \pm 1.8$ \\
& Nitrate & $0.52 \pm 0.035$ & $0.85 \pm 0.20$ & $1.7 \pm 0.45$ \\
Anderson impactor (all stages) & Ammonium & $0.14 \pm 0.0026$ & $0.23 \pm 0.015$ & $0.34 \pm 0.079$ \\
& nss Sulphate & $0.91 \pm 0.013$ & $1.1 \pm 0.090$ & $1.8 \pm 0.50$ \\
& nss Calcium & $0.039 \pm 0.0078$ & $0.17 \pm 0.0077$ & $1.1 \pm 0.28$ \\
& Methyl sulphonate & $0.024 \pm 0.0081$ & $0.028 \pm 0.00073$ & $0.054 \pm 0.0083$ \\
Wet DMPS and OPC & Total number $\left(\mathrm{cm}^{-3}\right)$ & $464 \pm 154$ & $834 \pm 460$ & $2230 \pm 1550$ \\
& Total volume $\left(\mu \mathrm{m}^{3} \mathrm{~cm}^{-3}\right)$ & $8.8 \pm 0.91$ & $6.0 \pm 2.7$ & $23.9 \pm 14.6$ \\
AMS (nonrefractory submicron) & $0.75 \pm 0.41$ & $0.29 \pm 0.092$ & $0.51 \pm 0.29$ \\
MAAP & Organics & $1.3 \pm 0.34$ & $0.99 \pm 0.31$ & $1.3 \pm 0.84$ \\
& Sulphate & $0.18 \pm 0.13$ & $0.30 \pm 0.095$ & $0.53 \pm 0.16$ \\
& Ammonium & $0.037 \pm 0.020$ & $0.044 \pm 0.014$ & $0.091 \pm 0.10$ \\
\hline
\end{tabular}

The high hygroscopicity mode, which is mainly present for the larger dry sizes, will correspond to the ss mode. The low hygroscopicity mode will be mainly attributable to Sarahan dust (Kaaden et al., 2009), as this is mainly present during the "African influence" period and is only manifested in the larger dry sizes. If these originated from combustion sources, they would have mainly been present in the smaller sizes.

An attempt was made to reconcile the growth factors measured using the HTDMA and those predicted using ADDEM based on the composition reported by the AMS, assuming that this is representative of the nss accumulation and Aitken modes.

ADDEM used the Pitzer-Simon-Clegg activity model (Clegg et al., 1998) for inorganic ions and UNIFAC (Fredenslund et al., 1975) for organic solutes, neglecting interactions between both the inorganic and organic fraction. The inorganic model is considered a benchmark thermodynamic tool, the organic model constantly evaluated and improved for aqueous systems significantly over recent years (e.g. Peng and Chan, 2001). The applicability of the ADDEM model to capture both sub and super-saturated aerosol growth has been evaluated using single particle instrumentation for idealized laboratory aerosol (e.g. Hanford et al., 2008; Rissman et al., 2007). Since no information regarding chemical speciation of the organic fraction was available, a representation based on a chemical structure for Suwannee River Fulvic acid, as described by Topping et al. (2005b), was used to calculate molar concentrations and provide functional group inputs for the UNIFAC model. The justification for using this model is covered by Topping et al. (2005b) and references therein. Briefly, comparisons with electrodynamic balance data exhibit excellent agreement with measured water uptake for the pure substance (Chan and Chan, 2003) while predicted growth factors similarly match empirically derived growth curves associated with aged organic aerosol (e.g. McFiggans

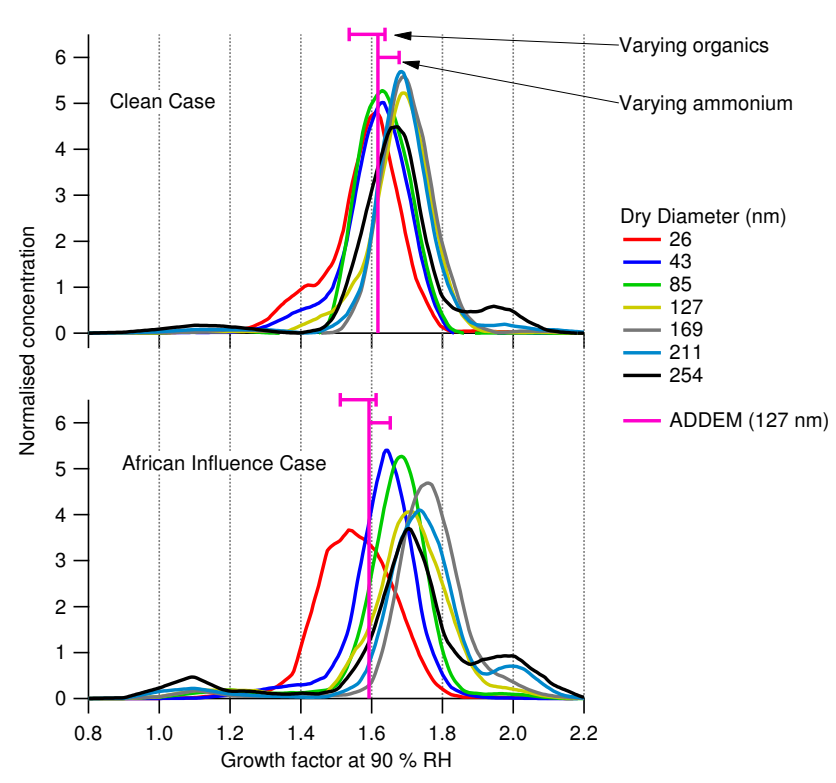

Fig. 9. HTDMA growth factor spectra, averaged over the case study periods, compared with ADDEM-predicted growth factors for $127 \mathrm{~nm}$ particles, based on AMS data. The error bars correspond to varying the organics between a molar ratio to the inorganics of $1 / 6$ and $1 / 2$. The ammonium was varied between a molar ratio to sulphate of 1 (ammonium bisulphate) and 2 (ammonium sulphate).

et al., 2005). In addition to adequately capturing non-ideality, hygroscopic growth is also sensitive to choice of dry density (Topping et al., 2005b). In this study, a pure component density of $1.5 \mathrm{~g} \mathrm{~cm}^{-3}$ was calculated using the ChemDraw 10.0 (CambridgeSoft, Cambridge, MA, USA) package for the chemical structure described earlier, and mixed dry and aqueous densities calculated using the mass fraction-mixing rule of Tang et al. (1997). 


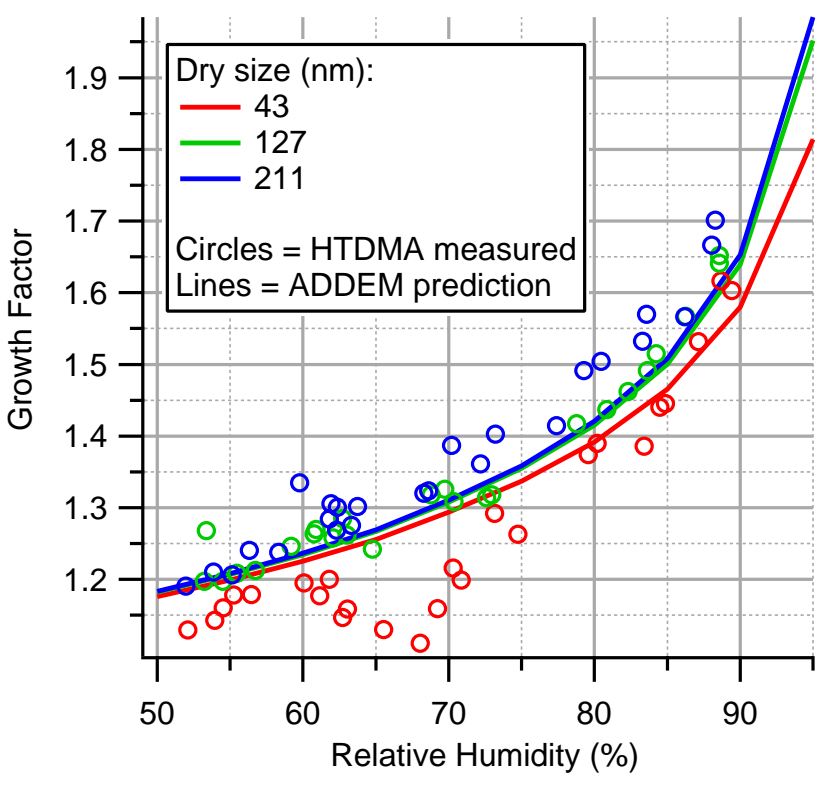

Fig. 10. Comparison of growth curves from an HTDMA humidogram (taken on 31 May 2007) and the corresponding ADDEM prediction based on AMS composition data taken at the time.

Figure 9 also shows a comparison of measured and predicted growth factors for the marine and African influenced cases. Based on the AMS loadings, the growth factors at $90 \%$ $\mathrm{RH}$ for $127 \mathrm{~nm}$ particles (this diameter was chosen to match the ambient accumulation mode) were predicted to be around 1.6. This compared to measured HTDMA growth factors of between 1.6 and 1.8, averaged before normalisation to remove any biases introduced by periods of low number concentrations.

To explore the possibility that an AMS measurement inaccuracy could be responsible for any disagreement, the ADDEM model runs were repeated after altering the mass concentrations to test for model sensitivity. First, the organic concentrations were altered between the concentrations that would correspond to molar ratios with the inorganics of $1 / 6$ and $1 / 2$. Secondly, the ammonium concentrations were varied between molar ratios of 1 (ammonium bisulphate) and 2 (ammonium sulphate). Both perturbations were found to only result in small variations. Increasing the organic mass fraction reduced the growth factors due to its low activity (Gysel et al., 2004). Reducing the ammonium increased the predicted growth factor due to the increased water activity of acidic particles. Interestingly, increasing the ammonium to that of ammonium sulphate did not suppress the growth factor as the effect of the increase in $\mathrm{pH}$ was cancelled out by the fractional increase in inorganics.

Given the resolution of $0.1-0.2$ imposed by the combined DMA transfer functions (Cubison et al., 2005), this agreement would seem reasonable, however there does seem to be a systematic positive bias. This could potentially result from some sea salt being internally mixed in the accumulation mode (which would not be detected by the AMS) but could also be caused by an artefact of the retrieval algorithm; a separate sea salt mode is not detected for any dry sizes below $211 \mathrm{~nm}$ but a minor fraction, if present, could inflate the reported accumulation mode if not correctly resolved.

Figure 10 shows a comparison between a humidograms measured on the night of 31 May 2007 and ADDEM growth predictions based on the AMS mass concentrations. This humidogram was chosen out of the several taken during the cruise as the others either did not have sufficient overlap with the AMS data or did not cover a wide enough RH range. The agreement is very good in terms of the shape of the curve with the exception of the low RH values for $43 \mathrm{~nm}$, where it is possible a plume from a combustion source may have interfered. The absolute values are very similar for $127 \mathrm{~nm}$ and $43 \mathrm{~nm}$, but for $211 \mathrm{~nm}$ the predicted growth factors again appear to be slightly low, could be due to interference from sea salt. Note that the mean growth factor used in the humidograms includes the entire growth factor spectrum and is insensitive to mixing state. Conceptually, it may be possible to separate according to mode before performing this comparison but as stated, the modes are often difficult to reliably resolve.

\section{Heterogeneous and multiphase chemistry}

Evidence for chemical processing of sea salt particles can be seen by comparing the halide concentrations relative to sodium reported by the impactors with the concentrations in seawater (Ayers et al., 1999). Figure 11 shows that the submicron chloride concentrations are found to be significantly depleted relative to seawater, while the supermicron chloride appears to only be slightly depleted, if this is even considered discernable from the measurement error. This depletion is usually ascribed to the chloride partitioning into the gas phase as $\mathrm{HCl}$ in response to the uptake of stronger acids such as nitric or sulphuric. The size dependency could be a manifestation of a combination of the larger surface area to volume ratio of the submicron particles (Song and Carmichael, 1999), or their longer atmospheric lifetime. The supermicron bromide is depleted, whereas the submicron bromide is enhanced. This is in line with a number of previous observations and has been seen as evidence for chemical processing (Sander et al., 2003), however the precise mechanism is the subject of debate. It is interesting to note that the African influenced period shows the least amount of processing of either bromine or chlorine, perhaps because the dust particles offer an alternative site for nitric and sulphuric acid uptake (Topping et al., 2004; Arimoto et al., 2004), suppressing halide displacement from the sea salt mode. However, it is also possible that some displaced acids are recondensing onto the dust particles (Sullivan et al., 2007), but the impactors would not be able to discern this. 
Table 2. Range (and median) concentrations $\left(\mathrm{pmol} \mathrm{m}^{-3}\right.$ ) and enrichment factors (EF) of iodide, iodate and soluble organic iodine (SOI) in sub- and super-micron aerosols.

\begin{tabular}{lllll}
\hline & \multicolumn{2}{c}{ Submicron } & \multicolumn{2}{c}{ Supermicron } \\
\hline & Conc. & EF & Conc. & EF \\
\hline Iodide & $1.8-11.2(3.3)$ & $850->5100(2300)$ & $1.6-8.7(3.1)$ & $37-170(73)$ \\
Iodate & $<1.3-4.3$ & $<180-800$ & $4.4-46.9(18.7)$ & $30-320(110)$ \\
SOI & $5.5-13(8.9)$ & & $<0.5-9.8$ & \\
\hline
\end{tabular}

Also in line with previous observations (Baker, 2004, 2005; Baker et al., 2000; Gäbler and Heumann, 1993), inorganic iodine was enriched over seawater concentrations in both the sub- and supermicron fractions, although enrichments were considerably greater in the submicron fraction (Table 2). Average surface seawater concentrations are 100 and $350 \mathrm{nmol} \mathrm{dm}^{-3}$ for iodide and iodate respectively in the tropical Atlantic (Truesdale et al., 2000), which implies that iodide was chiefly responsible for this enrichment in submicron inorganic iodine. Similarly to observations in other marine aerosol samples (Baker, 2005; Baker et al., 2000; Gilfedder et al., 2008), organic iodine made up the bulk of soluble iodine concentrations in the submicron particles and also contributed significantly to soluble iodine in the supermicron fraction. Given that organic iodine species are generally considered to make up a very small $(<1 \%)$ fraction of total iodine in open ocean surface waters (Wong and Cheng, 1998), this represents a very considerable enrichment and probably implies a significant secondary formation mechanism for aerosol organic iodine in the marine atmosphere.

The importance of the particle sizes on the uptake rate $\left(k_{\mathrm{t}}\right)$ of gas phase reactants can be estimated based on particle size and number from the assimilated distribution derived from the wet DMPS and OPC. For the sake of comparability with previous works, the same formula that has been used in similar previous studies was employed, which takes account of both the surface area and gas phase diffusion limitations on uptake (Coe et al., 2006; Williams et al., 2007; Schwartz, 1986):

$k_{\mathrm{t}, r}=\frac{4 \pi}{3}\left(\frac{r^{2}}{3 D_{\mathrm{g}}}+\frac{4 r}{3 \bar{c}_{\mathrm{g}} \gamma}\right)^{-1} r^{3}$

Where $r$ is the radius of the particle, $D_{\mathrm{g}}$ the gas diffusion coefficient, $\bar{c}_{\mathrm{g}}$ the mean kinetic velocity of the gas molecules and $\gamma$ the net uptake coefficient. In line with previous studies, the system modelled was for the uptake of hypoiodous acid (HOI) at ambient temperature and humidity, an important mechanism as identified by McFiggans et al. (2002). Other processes can and will be modelled as part of the halogen-aerosol interaction studies within RHAMBLE and will be the subject of future publications. The values of $D_{\mathrm{g}}$ and $\bar{c}_{\mathrm{g}}$ were calculated using the ambient measurements of

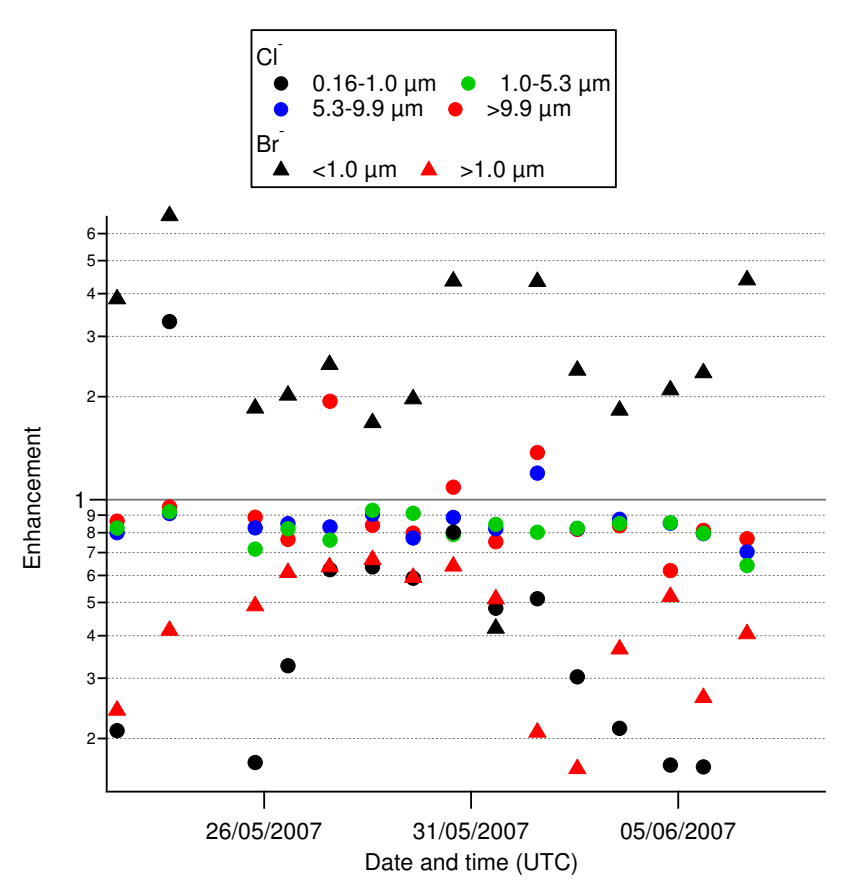

Fig. 11. Enhancement and depletion of halides in the impactor samples when compared with the values expected based on sodium concentrations and the typical composition of seawater. Anderson sampler data is used for Bromide, as this was below the detection limit of the CCI analysis.

temperature and pressure and the formulas specified by Coe et al. (2006). The results are shown in Fig. 12.

As with previous studies, the greatest source of uncertainty lies in $\gamma$, with a large difference between the assumed values of 1 and 0.03 . One thing that is important to note however is that the "true" $k_{\mathrm{t}, r}$ distribution may be somewhat different, given that it is possible that $\gamma$ may vary with particle composition and it is known the modes are chemically different.

For the clean case, the size-resolved and integrated uptake rates are within the range of measurements previously reported for the same geographical area by Williams et al. (2007). There is a slight disagreement with the wind speed dependency of the sea salt fraction; in this study, the peak of the coarse mode $\mathrm{d} k_{\mathrm{t}} / \mathrm{d} \log \left(\mathrm{D}_{\mathrm{p}}\right)$ distribution for the $\gamma=0.03$ 


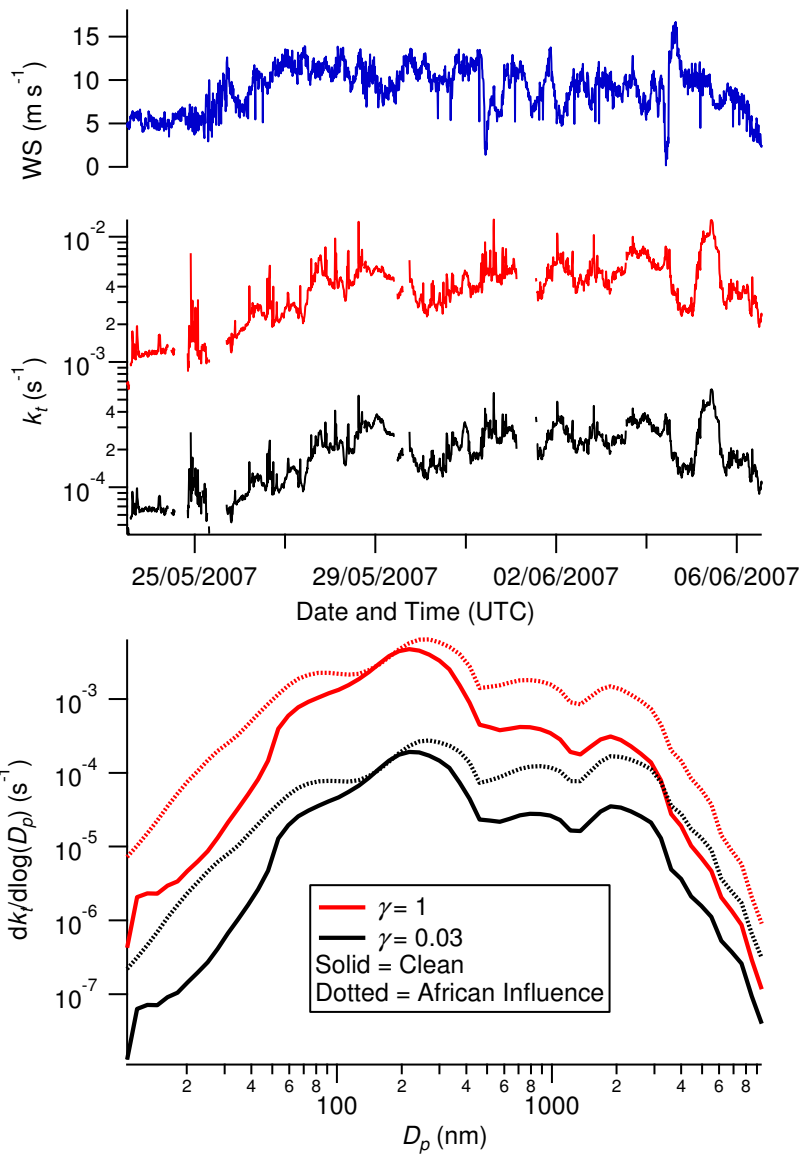

Fig. 12. Derived HOI uptake rates, based on the ensemble wet size distribution measurements on the Discovery. Also shown is the absolute wind speed, corrected for the heading and speed of the ship using navigational data.

case lies at around $3.5 \times 10^{-5} \mathrm{~s}^{-1}$, which is between the 2 and $8 \mathrm{~m} \mathrm{~s}^{-1}$ wind speed cases reported by Williams et al. (2007). Given the average wind speed of $10 \mathrm{~m} \mathrm{~s}^{-1}$ encountered during this study, this would seem slightly low in comparison.

During the period of African influence, $k_{\mathrm{t}}$ increases in line with the increases in particle number (by a factor of 1.9 from $2.4 \times 10^{-3}$ to $4.5 \times 10^{-3} \mathrm{~s}^{-1}$ for $\gamma=1$ and a factor of 2.2 from $1.1 \times 10^{-4}$ to $2.4 \times 10^{-4} \mathrm{~s}^{-1}$ for $\gamma=0.03$ ). Generally speaking, the greatest contributor to $k_{\mathrm{t}}$ is the accumulation mode particles, especially for the $\gamma=1$ case. Assuming there is no internally mixed sea salt, this will not participate directly in any halogen activation reactions, however it is still important, as it will act as an inert sink for the reactive gases such as HOI. In this regard, the addition of extra particles to this mode through the continental influence is significant as this will potentially inhibit the processes. However, there is also an increase in the ss particles during this period and their relative importance will depend on $\gamma$; for the $\gamma=1$ case, $40 \%$ of the increase in $k_{\mathrm{t}}$ is due to particles greater than $500 \mathrm{~nm}$ in diameter whereas for $\gamma=0.03,61 \%$ of the increase is due to

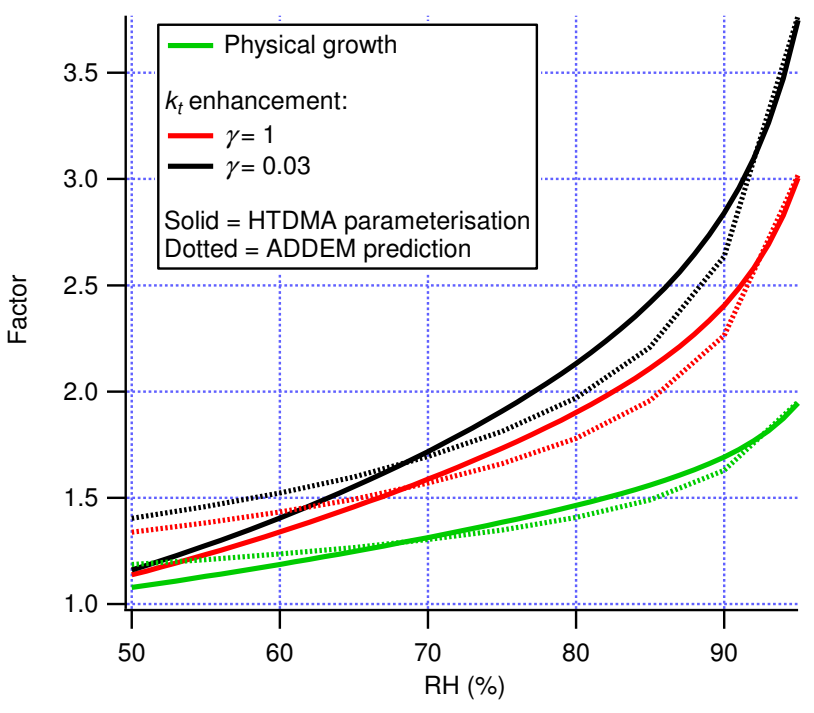

Fig. 13. Predicted effects of humidity on uptake rates for $211 \mathrm{~nm}$ particles at STP. The growth curves are those predicted by the HTDMA parameterisation and ADDEM during the "clean" period.

these particles. However, as stated earlier, the exact fraction of these which are composed of dust as opposed to sea salt is not easily resolved with this data.

To investigate the effect of humidity on the uptake rates, the enhancement due to hygroscopic growth was calculated for accumulation mode particles $(211 \mathrm{~nm}$, matched to the peak in the $k_{\mathrm{t}}$ distributions) with growth factors predicted by two methods for the marine period; the parameterised humidograms from the HTDMA and those predicted by ADDEM based on the average AMS composition. The calculations were performed at STP. The results are shown in Fig. 13. Also displayed are the physical growth factors for comparison.

The two treatments are in broad agreement, although they begin to diverge at humidities below around $60 \%$. This is probably a reflection on the humidograms used to generate the simulated growth curve for the "clean" case. Specifically, the humidogram taken on 29 May 2007 only collected data between 65 and $95 \% \mathrm{RH}$, so values below this range are extrapolated. The effect of hygroscopic growth is to increase the diameter by around a factor of 1.4 to 1.5 at $80 \% \mathrm{RH}$ relative to the dry size, which would be considered normal conditions during this study. This corresponds to an increase of a factor of 1.8 to 1.9 for $\gamma=1$ and 2.0 to 2.1 for $\gamma=0.03$.

\section{Conclusions}

Simultaneous measurements of atmospheric aerosol composition and properties were made at Cape Verde and the RRS Discovery during May 2007 as part of the RHAMBLE and ACMME projects. Particles encountered could be classified 
as either sea salt (ss), accumulation mode non sea salt (nss) and Saharan dust. Good agreement was found between the two platforms when the Discovery was in the region of Cape Verde. The nss fraction consisted mainly of sulphate and organics, with ammonium partially neutralising the sulphate. Halogen concentrations in the ss particles showed significant deviations from seawater relative to sodium, which shows evidence for atmospheric processing. The Discovery cruise track could be divided into sections according to aerosol composition and source region and two periods were identified for case study analysis, a "clean" period when the ship was travelling east from Cape Verde and an "African influence" period when the ship was in the Mauritanian upwelling region. The "clean" period was free of Saharan dust and showed reduced ss and nss particle concentrations.

Comparisons were performed between the measured growth factors and Aerosol Diameter Dependent Equilibrium Model (ADDEM) predictions based on measured composition, which is the first time that such a reconciliation exercise has been performed in the marine environment. Agreement was reasonable, although the ADDEM predictions were on average slightly low (around 1.6 compared to 1.7 at $90 \%$ $\mathrm{RH}$ ), especially when sea salt concentrations were high. This may imply a degree of internal mixing with sea salt, however this discrepancy could also be caused by an inversion artefact, in effect a manifestation of the fact that the separation of the ss and nss modes in the growth factor spectra is comparable to the maximum resolving power of the instrument (Cubison et al., 2005). The general shape of the growth curve between a measured humidogram and ADDEM predictions was also in very good agreement.

Predictions of the uptake rate of HOI were made to estimate the role of the aerosol in multiphase atmospheric chemistry and measurements of composition and hygroscopicity data was used to link the modes in the size-resolved uptake distribution to particle types. Uptake rates were found to be between $1.1 \times 10^{-4}$ to $2.4 \times 10^{-3} \mathrm{~s}^{-1}$ for the clean case, for accommodation coefficients of 0.03 and 1 respectively. In line with previous studies, the accumulation mode was found to be the dominant size fraction. As this work explicitly shows this to be mainly composed of sulphate and organics, these particles would represent relatively inert sink with regards to halogen cycling. The African influence increased the predicted uptake rates by a factor of around 2 through the addition of both accumulation mode and coarse particles (composed of both ss and dust) and the relative significance of the additional particles varied according to the accommodation coefficient used. Hygroscopicity was found to be a significant factor in uptake rates, with both ADDEM and the HTDMA parameterisations predicting an approximate doubling of uptake rates relative to dry particles. However, the largest source of uncertainty remains the net uptake coefficient parameter.
Acknowledgements. This work was supported by the National Environment Research Council through the Aerosol Characterisation and Modelling in the Marine Environment (ACMME, NE/E011454/1) and Reactive Halogens in the Marine Boundary Layer (RHAMBLE, NE/D006570/1) projects, both part of the Surface-Ocean/Lower Atmosphere Study (UK SOLAS) directed programme, and the $\mathrm{PhD}$ studentships of Nicholas Good (NER/S/A/2005/13221) and Martin Irwin (NER/S/A/2006/14036). Filter samples from the Cape Verde observatory were supported by Bruno Faria and Luis Mendes of the Instituto Nacional de Meteorologia e Geofisica, Cabo Verde, and Annelie Thomas and Eveline Neumann of the Leibniz-Institut für Troposphärenforschung e.V., Leipzig, Germany. ECMWF back trajectories were calculated using the British Atmospheric Data Centre web service (http://badc.nerc.ac.uk/data/ecmwf-trj/). Coastline data used in this paper was extracted from the National Geophysical Data Center (http://www.ngdc.noaa.gov/mgg/shorelines/shorelines.html).

Edited by: R. von Glasow

\section{References}

Allan, J. D., Jimenez, J. L., Williams, P. I., Alfarra, M. R., Bower, K. N., Jayne, J. T., Coe, H., and Worsnop, D. R.: Quantitative sampling using an Aerodyne aerosol mass spectrometer - 1 . Techniques of data interpretation and error analysis, J. Geophys. Res.-Atmos., 108, 4090, doi:10.1029/2002JD002358, 2003.

Allan, J. D., Bower, K. N., Coe, H., Boudries, H., Jayne, J. T., Canagaratna, M. R., Millet, D. B., Goldstein, A. H., Quinn, P. K., Weber, R. J., and Worsnop, D. R.: Submicron aerosol composition at Trinidad Head, California, during ITCT 2K2: Its relationship with gas phase volatile organic carbon and assessment of instrument performance, J. Geophys. Res.-Atmos., 109, D23S24, doi:10.1029/2003JD004208, 2004a.

Allan, J. D., Coe, H., Bower, K. N., Alfarra, M. R., Delia, A. E., Jimenez, J. L., Middlebrook, A. M., Drewnick, F., Onasch, T. B., Canagaratna, M. R., Jayne, J. T., and Worsnop, D. R.: A generalised method for the extraction of chemically resolved mass spectra from Aerodyne aerosol mass spectrometer data, J. Aerosol. Sci., 35, 909-922, 2004b.

Allan, J. D., Alfarra, M. R., Bower, K. N., Coe, H., Jayne, J. T., Worsnop, D. R., Aalto, P. P., Kulmala, M., Hytylinen, T., Cavalli, F., and Laaksonen, A.: Size and composition measurements of background aerosol and new particle growth in a Finnish forest during QUEST 2 using an Aerodyne Aerosol Mass Spectrometer, Atmos. Chem. Phys., 6, 315-327, 2006, http://www.atmos-chem-phys.net/6/315/2006/.

Allan, J. D., Baumgardner, D., Raga, G. B., Mayol-Bracero, O. L., Morales-Garca, F., Garca-Garca, F., Montero-Martnez, G., Borrmann, S., Schneider, J., Mertes, S., Walter, S., Gysel, M., Dusek, U., Frank, G. P., and Krmer, M.: Clouds and aerosols in Puerto Rico - a new evaluation, Atmos. Chem. Phys., 8, 1293-1309, 2008, http://www.atmos-chem-phys.net/8/1293/2008/.

Arimoto, R., Zhang, X. Y., Huebert, B. J., Kang, C. H., Savoie, D. L., Prospero, J. M., Sage, S. K., Schloesslin, C. A., Khaing, H. M., and Oh, S. N.: Chemical composition of atmospheric aerosols from Zhenbeitai, China, and Gosan, South 
Korea, during ACE-Asia, J. Geophys. Res., 109, D19S04, doi:10.1029/2003jd004323, 2004.

Ayers, G. P., Ivey, J. P., and Gillett, R. W.: Coherence between Seasonal Cycles of Dimethyl Sulfide, Methanesulfonate and Sulfate in Marine Air, Nature, 349, 404-406, 1991.

Ayers, G. P., Gillett, R. W., Cainey, J. M., and Dick, A. L.: Chloride and bromide loss from sea-salt particles in southern ocean air, J. Atmos. Chem., 33, 299-319, 1999.

Baker, A. R., Thompson, D., Campos, M. L. A. M., Parry, S. J., and Jickells, T. D.: Iodine concentration and availability in atmospheric aerosol, Atmos. Environ., 34, 4331-4336, 2000.

Baker, A. R., Kelly, S. D., Biswas, K. F., Witt, M., and Jickells, T. D.: Atmospheric deposition of nutrients to the Atlantic Ocean, Geophys. Res. Lett., 30, 2296, doi:10.1029/2003GL018518, 2003.

Baker, A. R.: Inorganic iodine speciation in tropical Atlantic aerosol, Geophys. Res. Lett., 31, L23S02, doi:10.1029/2004g1020144, 2004.

Baker, A. R.: Marine aerosol iodine chemistry: The importance of soluble organic iodine, Environ. Chem., 2, 295-298, doi:10.1071/En05070, 2005.

Baker, A. R., Weston, K., Kelly, S. D., Voss, M., Streu, P., and Cape, J. N.: Dry and wet deposition of nutrients from the tropical Atlantic atmosphere: Links to primary productivity and nitrogen fixation, Deep-Sea Res. Pt. I, 54, 1704-1720, doi:10.1016/j.dsr.2007.07.001, 2007.

Bates, T. S., Calhoun, J. A., and Quinn, P. K.: Variations In The Methanesulfonate To Sulfate Molar Ratio In Submicrometer Marine Aerosol-Particles Over The South-Pacific Ocean, J. Geophys. Res.-Atmos., 97, 9859-9865, 1992.

Birmili, W., Stratmann, F., and Wiedensohler, A.: Design of a DMA-based size spectrometer for a large particle size range and stable operation, J. Aerosol. Sci., 30, 549-553, 1999.

Canagaratna, M. R., Jayne, J. T., Jimenez, J. L., Allan, J. D., Alfarra, M. R., Zhang, Q., Onasch, T. B., Drewnick, F., Coe, H., Middlebrook, A., Delia, A., Williams, L. R., Trimborn, A. M., Northway, M. J., DeCarlo, P. F., Kolb, C. E., Davidovits, P., and Worsnop, D. R.: Chemical and microphysical characterization of ambient aerosols with the Aerodyne aerosol mass spectrometer, Mass Spectrom. Rev., 26, 185-222, 2007.

Chan, M. N. and Chan, C. K.: Hygroscopic properties of two model humic-like substances and their mixtures with inorganics of atmospheric importance, Environ. Sci. Technol., 37, 5109-5115, doi:10.1021/Es034272o, 2003.

Claquin, T., Schulz, M., and Balkanski, Y. J.: Modeling the mineralogy of atmospheric dust sources, J. Geophys. Res.-Atmos., 104, 22243-22256, 1999.

Clegg, S. L., Brimblecombe, P., and Wexler, A. S.: Thermodynamic model of the system $\mathrm{H}+-\mathrm{NH}_{4}+-\mathrm{SO}_{4}^{2}-\mathrm{NO}_{3}-\mathrm{H}_{2} \mathrm{O}$ at tropospheric temperatures, J. Phys. Chem. A., 102, 2137-2154, 1998.

Coe, H., Allan, J. D., Alfarra, M. R., Bower, K. N., Flynn, M. J., McFiggans, G. B., Topping, D. O., Williams, P. I., O'Dowd, C. D., Dall'Osto, M., Beddows, D. C. S., and Harrison, R. M.: Chemical and physical characteristics of aerosol particles at a remote coastal location, Mace Head, Ireland, during NAMBLEX, Atmos. Chem. Phys., 6, 3289-3301, 2006, http://www.atmos-chem-phys.net/6/3289/2006/.

Cubison, M. J., Coe, H., and Gysel, M.: A modified hygroscopic tandem DMA and a data retrieval method based on optimal esti- mation, J. Aerosol. Sci., 36, 846-865, 2005.

DeCarlo, P. F., Slowik, J. G., Worsnop, D. R., Davidovits, P., and Jimenez, J. L.: Particle Morphology and Density Characterization by Combined Mobility and Aerodynamic Diameter Measurements, Part 1: Theory, Aerosol Sci. Technol., 38, 11851205, 2004.

DeCarlo, P. F., Kimmel, J. R., Trimborn, A., Northway, M. J., Jayne, J. T., Aiken, A. C., Gonin, M., Fuhrer, K., Horvath, T., Docherty, K. S., Worsnop, D. R., and Jimenez, J. L.: Field-deployable, high-resolution, time-of-flight aerosol mass spectrometer, Anal. Chem., 78, 8281-8289, 2006.

Demokritou, P., Lee, S. J., Ferguson, S. T., and Koutrakis, P.: A compact multistage (cascade) impactor for the characterization of atmospheric' aerosols, J. Aerosol. Sci., 35, 281-299, doi:10.1016/j.jaerosci.2003.09.003, 2004.

Facchini, M. C., Decesari, S., Rinaldit, M., Carbone, C., Finessi, E., Mircea, M., Fuzzi, S., Moretti, F., Tagliavini, E., Ceburnis, D., and O'Dowd, C. D.: Important Source of Marine Secondary Organic Aerosol from Biogenic Amines, Environ. Sci. Technol., 42, 9116-9121, doi:10.1021/es8018385, 2008.

Formenti, P., Elbert, W., Maenhaut, W., Haywood, J., and Andreae, M. O.: Chemical composition of mineral dust aerosol during the Saharan Dust Experiment (SHADE) airborne campaign in the Cape Verde region, September 2000, J. Geophys. Res.-Atmos., 108, 8576, doi:10.1029/2002jd002648, 2003.

Forster, P., Ramaswamy, V., Artaxo, P., Berntsen, T., Betts, R., Fahey, D. W., Haywood, J., Lean, J., Lowe, D. C., Myhre, G., Nganga, J., Prinn, R., Raga, G., Schulz, M., and Dorland, R. V.: Changes in Atmospheric Constituents and in Radiative Forcing, in: Climate Change 2007: The Physical Science Basis., edited by: Solomon, S., Qin, D., Manning, M., Chen, Z., Marquis, M., Averyt, K. B., Tignor, M., and Miller, H. L., Cambridge Univ. Press, Cambridge; New York, 129-234, 2007.

Fredenslund, A., Jones, R. L., and Prausnitz, J. M.: Groupcontribution estimation of activity coefficients in nonideal liquid mixtures, AIChE J, 21, 1086-1099, 1975.

Gäbler, H. E. and Heumann, K. G.: Determination of Particulate Iodine in Aerosols from Different Regions by Size Fractionating Impactor Sampling and Idms, Int. J. Environ. An. Ch., 50, 129146, 1993.

Gilfedder, B. S., Lai, S. C., Petri, M., Biester, H., and Hoffmann, T.: Iodine speciation in rain, snow and aerosols, Atmos. Chem. Phys., 8, 6069-6084, 2008,

http://www.atmos-chem-phys.net/8/6069/2008/.

Good, N., Topping, D. O., Allan, J. D., Flynn, M., Fuentes, E., Irwin, M., Williams, P. I., Coe, H., and McFiggans, G.: Consistency between parameterisations of aerosol hygroscopicity and CCN activity during the RHaMBLe Discovery cruise, Atmos. Chem. Phys. Discuss., 9, 22659-22692, 2009, http://www.atmos-chem-phys-discuss.net/9/22659/2009/.

Gysel, M., Weingartner, E., Nyeki, S., Paulsen, D., Baltensperger, U., Galambos, I., and Kiss, G.: Hygroscopic properties of water-soluble matter and humic-like organics in atmospheric fine aerosol, Atmos. Chem. Phys., 4, 35-50, 2004, http://www.atmos-chem-phys.net/4/35/2004/.

Gysel, M., Crosier, J., Topping, D. O., Whitehead, J. D., Bower, K. N., Cubison, M. J., Williams, P. I., Flynn, M. J., McFiggans, G. B., and Coe, H.: Closure study between chemical composition and hygroscopic growth of aerosol particles during TORCH2, 
Atmos. Chem. Phys., 7, 6131-6144, 2007,

http://www.atmos-chem-phys.net/7/6131/2007/.

Gysel, M., McFiggans, G. B., and Coe, H.: Inversion of tandem differential mobility analyser (TDMA) measurements, J. Aerosol. Sci., 40, 134-151, doi:10.1016/j.jaerosci.2008.07.013, 2009.

Hanford, K. L., Mitchem, L., Reid, J. P., Clegg, S. L., Topping, D. O., and McFiggans, G. B.: Comparative thermodynamic studies of aqueous glutaric acid, ammonium sulfate and sodium chloride aerosol at high humidity, J. Phys. Chem. A., 112, 9413-9422, doi:10.1021/Jp802520d, 2008.

Haywood, J., Francis, P., Osborne, S., Glew, M., Loeb, N., Highwood, E., Tanre, D., Myhre, G., Formenti, P., and Hirst, E.: Radiative properties and direct radiative effect of Saharan dust measured by the C-130 aircraft during SHADE: 1 . Solar spectrum, J. Geophys. Res.-Atmos., 108, 8577, doi:10.1029/2002jd002687, 2003.

Hoppel, W. A., Frick, G. M., and Larson, R. E.: Effect of Nonprecipitating Clouds on the Aerosol Size Distribution in the Marine Boundary-Layer, Geophys. Res. Lett., 13, 125-128, 1986.

Jayne, J. T., Leard, D. C., Zhang, X. F., Davidovits, P., Smith, K. A., Kolb, C. E., and Worsnop, D. R.: Development of an aerosol mass spectrometer for size and composition analysis of submicron particles, Aerosol Sci. Technol., 33, 49-70, 2000.

Jickells, T. D., Kelly, S. D., Baker, A. R., Biswas, K., Dennis, P. F., Spokes, L. J., Witt, M., and Yeatman, S. G.: Isotopic evidence for a marine ammonia source, Geophys. Res. Lett., 30, 1374, doi:10.1029/2002g1016728, 2003.

Jimenez, J. L., Jayne, J. T., Shi, Q., Kolb, C. E., Worsnop, D. R., Yourshaw, I., Seinfeld, J. H., Flagan, R. C., Zhang, X., Smith, K. A., Morris, J. W., and Davidovits, P.: Ambient aerosol sampling using the Aerodyne Aerosol Mass Spectrometer, J. Geophys. Res.-Atmos., 108, 8425, doi:10.1029/2001JD001213, 2003.

Kaaden, N., Massling, A., Schladitz, A., Muller, T., Kandler, K., Schutz, L., Weinzierl, B., Petzold, A., Tesche, M., Leinert, S., Deutscher, C., Ebert, M., Weinbruch, S., and Wiedensohler, A.: State of mixing, shape factor, number size distribution, and hygroscopic growth of the Saharan anthropogenic and mineral dust aerosol at Tinfou, Morocco, Tellus B, 61, 51-63, doi:10.1111/j.1600-0889.2008.00388.x, 2009.

Kawamura, K. and Gagosian, R. B.: Implications Of OmegaOxocarboxylic Acids In The Remote Marine Atmosphere For Photooxidation Of Unsaturated Fatty-Acids, Nature, 325, 330332, 1987.

Köhler, H.: The nucleus in and the growth of hygroscopic droplets, Trans. Faraday Soc., 32, 1152-1161, doi:10.1039/TF9363201152, 1936.

Kreidenweis, S. M., Koehler, K., DeMott, P. J., Prenni, A. J., Carrico, C., and Ervens, B.: Water activity and activation diameters from hygroscopicity data - Part I: Theory and application to inorganic salts, Atmos. Chem. Phys., 5, 1357-1370, 2005, http://www.atmos-chem-phys.net/5/1357/2005/.

Lack, D. A., Cappa, C. D., Covert, D. S., Baynard, T., Massoli, P., Sierau, B., Bates, T. S., Quinn, P. K., Lovejoy, E. R., and Ravishankara, A. R.: Bias in filter-based aerosol light absorption measurements due to organic aerosol loading: Evidence from ambient measurements, Aerosol Sci. Technol., 42, 1033-1041, doi:10.1080/02786820802389277, 2008.

Lee, J. D., McFiggans, G., Allan, J. D., Baker, A. R., Ball, S. M., Benton, A. K., Carpenter, L. J., Commane, R., Finley, B. D.,
Evans, M., Fuentes, E., Furneaux, K., Goddard, A., Good, N., Hamilton, J. F., Heard, D. E., Herrmann, H., Hollingsworth, A., Hopkins, J. R., Ingham, T., Irwin, M., Jones, C. E., Jones, R. L., Keene, W. C., Lawler, M. J., Lehmann, S., Lewis, A. C., Long, M. S., Mahajan, A., Methven, J., Moller, S. J., Mller, K., Mller, T., Niedermeier, N., O’Doherty, S., Oetjen, H., Plane, J. M. C., Pszenny, A. A. P., Read, K. A., Saiz-Lopez, A., Saltzman, E. S., Sander, R., von Glasow, R., Whalley, L., Wiedensohler, A., and Young, D.: Reactive Halogens in the Marine Boundary Layer (RHaMBLe): the tropical North Atlantic experiments, Atmos. Chem. Phys. Discuss., 9, 21717-21783, 2009,

http://www.atmos-chem-phys-discuss.net/9/21717/2009/.

McFiggans, G., Cox, R. A., Mossinger, J. C., Allan, B. J., and Plane, J. M. C.: Active chlorine release from marine aerosols: Roles for reactive iodine and nitrogen species, J. Geophys. Res.-Atmos., 107, 4271, doi:10.1029/2001jd000383, 2002.

McFiggans, G., Alfarra, M. R., Allan, J., Bower, K., Coe, H., Cubison, M., Topping, D., Williams, P., Decesari, S., Facchini, C., and Fuzzi, S.: Simplification of the representation of the organic component of atmospheric particulates, Faraday Discuss., 130, 341-362, 2005.

Millero, F. J.: The Physical Chemistry of Seawater, Annu. Rev. Earth Planet. Sci., 2, 101-150, 1974.

Mochida, M., Umemoto, N., Kawamura, K., Lim, H. J., and Turpin, B. J.: Bimodal size distributions of various organic acids and fatty acids in the marine atmosphere: Influence of anthropogenic aerosols, Asian dusts, and sea spray off the coast of East Asia, J. Geophys. Res.-Atmos., 112, D15209, doi:10.1029/2006jd007773, 2007.

Müller, K., Lehmann, S., van Pinxteren, D., Gnauk, T., Niedermeier, N., Wiedensohler, A., and Herrmann, H.: Particle characterization at the Cape Verde atmospheric observatory during the 2007 RHaMBLe intensive, Atmos. Chem. Phys. Discuss., 9, 22739-22771, 2009,

http://www.atmos-chem-phys-discuss.net/9/22739/2009/.

Novakov, T. and Penner, J. E.: Large Contribution of Organic Aerosols to Cloud-Condensation-Nuclei Concentrations, Nature, 365, 823-826, 1993.

Novakov, T., Corrigan, C. E., Penner, J. E., Chuang, C. C., Rosario, O., and Mayol-Bracero, O. L.: Organic aerosols in the Caribbean trade winds: A natural source?, J. Geophys. Res.-Atmos., 102, 21307-21313, 1997.

O’Dowd, C. D., Facchini, M. C., Cavalli, F., Ceburnis, D., Mircea, M., Decesari, S., Fuzzi, S., Yoon, Y. J., and Putaud, J. P.: Biogenically driven organic contribution to marine aerosol, Nature, 431, 676-680, 2004.

O'Dowd, C. D. and De Leeuw, G.: Marine aerosol production: a review of the current knowledge, Phil. Trans. R. Soc. A, 365, 1753-1774, doi:10.1098/rsta.2007.2043, 2007.

Peng, C. G. and Chan, C. K.: The water cycles of water-soluble organic salts of atmospheric importance, Atmos. Environ., 35, 1183-1192, 2001.

Petzold, A., Schloesser, H., Sheridan, P. J., Arnott, W. P., Ogren, J. A., and Virkkula, A.: Evaluation of multiangle absorption photometry for measuring aerosol light absorption, Aerosol Sci. Technol., 39, 40-51, doi:10.1080/027868290901945, 2005.

Quinn, P. K., Covert, D. S., Bates, T. S., Kapustin, V. N., Ramseybell, D. C., and Mcinnes, L. M.: Dimethylsulfide Cloud Condensation Nuclei Climate System - Relevant Size-Resolved Mea- 
surements of the Chemical and Physical-Properties of Atmospheric Aerosol-Particles, J. Geophys. Res.-Atmos., 98, 1041110427, 1993.

Quinn, P. K., Bates, T. S., Baynard, T., Clarke, A. D., Onasch, T. B., Wang, W., Rood, M. J., Andrews, E., Allan, J., Carrico, C. M., Coffman, D., and Worsnop, D.: Impact of particulate organic matter on the relative humidity dependence of light scattering: A simplified parameterization, Geophys. Res. Lett., 32, L22809, doi:10.1029/2005GL024322, 2005.

Raes, F., Van Dingenen, R., Vignati, E., Wilson, J., Putaud, J. P., Seinfeld, J. H., and Adams, P.: Formation and cycling of aerosols in the global troposphere, Atmos. Environ., 34, 4215-4240, 2000.

Ravishankara, A. R.: Heterogeneous and multiphase chemistry in the troposphere, Science, 276, 1058-1065, 1997.

Read, K. A., Mahajan, A. S., Carpenter, L. J., Evans, M. J., Faria, B. V. E., Heard, D. E., Hopkins, J. R., Lee, J. D., Moller, S. J., Lewis, A. C., Mendes, L., McQuaid, J. B., Oetjen, H., SaizLopez, A., Pilling, M. J., and Plane, J. M. C.: Extensive halogenmediated ozone destruction over the tropical Atlantic Ocean, Nature, 453, 1232-1235, doi:10.1038/Nature07035, 2008.

Rissman, T. A., Varutbangkul, V., Surratt, J. D., Topping, D. O., McFiggans, G., Flagan, R. C., and Seinfeld, J. H.: Cloud condensation nucleus $(\mathrm{CCN})$ behavior of organic aerosol particles generated by atomization of water and methanol solutions, Atmos. Chem. Phys., 7, 2949-2971, 2007,

http://www.atmos-chem-phys.net/7/2949/2007/.

Sander, R., Keene, W. C., Pszenny, A. A. P., Arimoto, R., Ayers, G. P., Baboukas, E., Cainey, J. M., Crutzen, P. J., Duce, R. A., Hnninger, G., Huebert, B. J., Maenhaut, W., Mihalopoulos, N., Turekian, V. C., and Van Dingenen, R.: Inorganic bromine in the marine boundary layer: a critical review, Atmos. Chem. Phys., 3, 1301-1336, 2003, http://www.atmos-chem-phys.net/3/1301/2003/.

Schwartz, S. E.: Mass-transport considerations pertinent to aqueous phase reactions of gases in liquid-water clouds, in: Chemistry of multiphase atmospheric systems, edited by: Jaeschke, W. J., NATO ASI Series. Series G, Ecological sciences, Vol. 6, Springer, Berlin, 415-471, 1986.

Song, C. H. and Carmichael, G. R.: The aging process of naturally emitted aerosol (sea-salt and mineral aerosol) during long range transport, Atmos. Environ., 33, 2203-2218, 1999.
Sullivan, R. C., Guazzotti, S. A., Sodeman, D. A., Tang, Y. H., Carmichael, G. R., and Prather, K. A.: Mineral dust is a sink for chlorine in the marine boundary layer, Atmos. Environ., 41, 7166-7179, 2007.

Tang, I. N.: Thermodynamic and optical properties of mixed-salt aerosols of atmospheric importance, J. Geophys. Res.-Atmos., 102, 1883-1893, 1997.

Topping, D. O., Coe, H., McFiggans, G. B., Burgess, R., Allan, J. D., Alfarra, M. R., Bower, K. N., Choularton, T. W., Decesari, S., and Facchini, M. C.: Aerosol chemical characteristics from sampling conducted on the island of Jeju, Korea during ACE Asia, Atmos. Environ., 38, 2111-2123, 2004.

Topping, D. O., McFiggans, G. B., and Coe, H.: A curved multicomponent aerosol hygroscopicity model framework: Part 1 -Inorganic compounds, Atmos. Chem. Phys., 5, 1205-1222, 2005a, http://www.atmos-chem-phys.net/5/1205/2005/.

Topping, D. O., McFiggans, G. B., and Coe, H.: A curved multicomponent aerosol hygroscopicity model framework: Part 2 Including organic compounds, Atmos. Chem. Phys., 5, 1223$1242,2005 b$, http://www.atmos-chem-phys.net/5/1223/2005/.

Truesdale, V. W., Bale, A. J., and Woodward, E. M. S.: The meridional distribution of dissolved iodine in near-surface waters of the Atlantic Ocean, Prog. Oceanogr., 45, 387-400, 2000.

von Glasow, R., Sander, R., Bott, A., and Crutzen, P. J.: Modeling halogen chemistry in the marine boundary layer -2 . Interactions with sulfur and the cloud-covered MBL, J. Geophys. Res.Atmos., 107, 4323, doi:10.1029/2001jd000943, 2002.

Williams, P. I., Gallagher, M. W., Choularton, T. W., Coe, H., Bower, K. N., and McFiggans, G.: Aerosol development and interaction in an urban plume, Aerosol Sci. Technol., 32, 120-126, 2000.

Williams, P. I., McFiggans, G., and Gallagher, M. W.: Latitudinal aerosol size distribution variation in the Eastern Atlantic Ocean measured aboard the FS-Polarstern, Atmos. Chem. Phys., 7, 2563-2573, 2007, http://www.atmos-chem-phys.net/7/2563/2007/.

Wong, G. T. F. and Cheng, X. H.: Dissolved organic iodine in marine waters: Determination, occurrence and analytical implications, Mar. Chem., 59, 271-281, 1998. 